\title{
Glosa do UchWAey SĄDU NaJWYŻSZEGo Z DNIA 8 LISTOPADA 2019 R. III CZP 26/19
}

Dokument z podpisem uznanym przez notariusza ${ }^{1}$ za własnoręczny (art. 88 ustawy z dnia 14 lutego 1991 r. - Prawo o notariacie, tekst jednolity: Dz. U. z 2019 r. poz. 540 z późn. zm.) jest dokumentem prywatnym $\mathrm{z}$ podpisem urzędowo poświadczonym $\mathrm{w}$ rozumieniu art. 788 § 1 K.p.c. ${ }^{2}$

Przytoczona powyżej uchwała wydana została przez Sąd Najwyższy w dniu 8 listopada 2019 r., w sprawie III CZP 26/19, w odpowiedzi na pytanie prawne Sądu Rejonowego z dnia 5 kwietnia 2019 r. zmierzające do ustalenia, czy poświadczenie przez notariusza w trybie art. $88 \mathrm{zd}$. drugie Prawa o notariacie, że stawająca przed nim osoba uznała podpis na dokumencie prywatnym za własnoręczny, jest urzędowym poświadczeniem podpisu w rozumieniu art. 788 § 1 K.p.c.

Przedstawione Sądowi Najwyższemu zagadnienie prawne powstało w następującym, nieskomplikowanym stanie faktycznym: wnioskodawca,

* Mgr, Katolicki Uniwersytet Lubelski Jana Pawła II, e-mail: katarzyna.woch@kul.pl, https:/ / orcid.org/0000-0003-1176-6135.

1 Na wstępie wskazać należy, że zarówno w zagadnieniu prawnym skierowanym do Sądu Najwyższego, jak i samej uchwale wystąpiła oczywista omyłka. Z treści art. 88 zd. drugie ustawy z dnia 14 lutego 1991 r. - Prawo o notariacie, tekst jednolity: Dz. U. z 2019 r. poz. 540 z późn. zm. (dalej: Prawo o notariacie) jednoznacznie wynika, że chodzi o uznanie złożonego podpisu przed notariuszem za własnoręczny, nie zaś o uznanie złożonego podpisu przez notariusza za własnoręczny. O dokumencie z podpisem uznanym przed notariuszem za własnoręczny mowa również na stronie 4 uzasadnienia do uchwały. $\mathrm{Z}$ tego też względu autor glosy w dalszej części posługiwać się będzie ustawowym sformułowaniem „podpis uznany przed notariuszem za własnoręczny”.

2 Ustawa z dnia 17 kwietnia 1964 r. - Kodeks postępowania cywilnego, tekst jednolity: Dz. U. z 2019 r. poz. 1460 z późn. zm. (dalej: K.p.c.). 
jako następca prawny pierwotnego wierzyciela, wniósł o nadanie klauzuli wykonalności nakazowi zapłaty w postępowaniu upominawczym w trybie art. 788 K.p.c. Jako dokument stwierdzający następstwo prawne wnioskodawcy wskazano umowę sprzedaży wierzytelności, która zawierała notarialne poświadczenie stwierdzające, że wierzyciel uznał złożony na tej umowie podpis za własny (własnoręczny). Referendarz sądowy, rozpoznający tenże wniosek, stwierdził, że przyjęcie oświadczenia o uznaniu wcześniej złożonego podpisu za własny nie jest równoznaczne $\mathrm{z}$ urzędowym poświadczeniem podpisu w rozumieniu art. 788 $\S 1$ K.p.c. w zw. z art. 88 Prawa o notariacie i w konsekwencji go oddalił. Z tym rozstrzygnięciem nie zgodził się wnioskodawca, który złożył skargę na postanowienie referendarza sądowego.

W uzasadnieniu przedstawionego zagadnienia prawnego sąd rozstrzygający skargę wnioskodawcy na orzeczenie referendarza argumentował m.in., że uznanie przez stawającego przed notariuszem podpisu złożonego wcześniej za własny nie jest formą równoważną z poświadczeniem, o jakim mowa w art. $88 \mathrm{zd}$. pierwsze Prawa o notariacie i stanowi odrębną czynność poświadczeniową. Zwrócił uwagę, że oświadczenie o złożeniu podpisu może być obarczone błędem lub inną wadą oświadczenia woli. W ocenie sądu, w sytuacji gdy notariusz opiera się wyłącznie na relacji innej osoby, w dodatku zainteresowanej, odpadają przymioty obiektywizmu i niezależności notariusza, co w konsekwencji rodzi poważne niebezpieczeństwo dla obrotu prawnego.

Odnosząc się do problematyki komentowanego orzeczenia, w pierwszej kolejności przypomnieć należy, że stosownie do treści art. 788 $\S 1$ K.p.c., jeżeli uprawnienie lub obowiązek po powstaniu tytułu egzekucyjnego lub w toku sprawy przed wydaniem tytułu przeszły na inną osobę, sąd nada klauzulę wykonalności na rzecz lub przeciwko tej osobie, gdy przejście to będzie wykazane dokumentem urzędowym lub prywatnym z podpisem urzędowo poświadczonym. W orzecznictwie ${ }^{3}$ i literaturze przedmiotu $^{4}$ podkreśla się, że przywołana regulacja jest przepisem prawa procesowego, który ma dwojakie znaczenie. $Z$ jednej strony pełni on

3 Tak m.in. Sąd Najwyższy w uchwale z dnia 13 maja 2015 r., III CZP 15/15, OSNC 2016, nr 5, poz. 56 oraz z dnia 17 listopada 2017 r., III CZP 53/17, OSNC 2018, nr 7-8, poz. 73.

4 Stanowisko Sądu Najwyższego wyrażone w wymienionych powyżej uchwałach zostało zaaprobowane m.in. przez K. Kowalskiego, Glosa do uchwaty Sądu Najwyższego z 13.05.2015 r., III CZP 15/15, Rejent 2017, nr 11(319), s. 117-118 oraz D. Pucia, Postępowanie w przedmiocie nadania klauzuli wykonalności na rzecz następcy prawnego, w: Aktualne 
funkcję wykonawczą, prowadząc do aktualizacji tytułu wykonawczego w aspekcie podmiotowym (co do osoby wierzyciela lub dłużnika). Prawa lub obowiązki objęte tytułem egzekucyjnym mogą przechodzić na inne podmioty na skutek różnych zdarzeń prawnych, takich jak m.in.: śmierć dłużnika lub wierzyciela, przelew wierzytelności, przejęcie długu, utrata bytu prawnego przez wierzyciela lub dłużnika niebędącego osobą fizyczną i przejęcie majątku przez następcę prawnego, czy też wstąpienie w prawa wierzyciela ${ }^{5}$. Wskazany przepis stwarza zaś możliwość prowadzenia egzekucji, jeżeli zaszły zmiany w osobach wierzyciela lub dłużnika po powstaniu tytułu egzekucyjnego lub w toku sprawy, a więc kiedy dłużnik przestał być dłużnikiem lub wierzyciel przestał być wierzycielem, a w ich miejsce wstąpiły inne osoby ${ }^{6}$.

$\mathrm{Z}$ drugiej strony przepis art. $788 \S 1$ K.p.c. pełni funkcję dowodową7. Określa bowiem, jakie środki dowodowe i w jakiej formie sporządzone mogą stanowić podstawę ustalenia przez sąd, że doszło do sukcesji prawa lub obowiązku określonego w tytule egzekucyjnym, pozwalającej na nadanie klauzuli na rzecz lub przeciwko innej osobie niż określona w tytule. Oznacza to, że postępowanie w przedmiocie klauzuli wykonalności z zaznaczeniem przejścia uprawnień lub obowiązków jest sformalizowane, przedstawione zaś przez wnioskodawcę dowody z dokumentów odgrywają podstawowe znaczenie ${ }^{8}$. Wykazanie przed sądem zmian podmiotowych powstałych na skutek przejścia uprawnień lub obowiązków może nastąpić bowiem wyłącznie albo za pomocą dokumentu

problemy prawa materialnego i procesowego cywilnego, red. E. Marszałkowska-Krześ, Wroclaw 2019, s. 101.

5 A. Zieliński, K. Flaga-Gieruszyńska, Kodeks postępowania cywilnego. Komentarz, wyd. 10, Warszawa 2019, [System Informacji Prawnej Legalis, dostęp: 5.01.2020 r.].

6 Z. Szczurek, Kiedy istnieje potrzeba w postępowaniu cywilnym klauzuli wykonalności na rzecz lub przeciwko osobom niewymienionym w tytule egzekucyjnym, Gdańskie Studia Prawnicze 2011, t. 26, nr 2, s. 435.

7 Samo przejście uprawnień (obowiązków) jest kategorią prawa materialnego. Przejście uprawnień (obowiązków) jest bowiem konsekwencją wystąpienia określonych przesłanek, o których mowa w przepisach prawa materialnego.

8 M. Stanik, Dowody z dokumentów poświadczonych za zgodność z oryginałem przez profesjonalnego petnomocnika w postępowaniu w sprawie o wpis w Krajowym Rejestrze Sąowym, Zeszyty Prawnicze 2013, t. 13, z. 3, s. 174. 
urzędowego $^{9}$, albo za pomocą dokumentu prywatnego ${ }^{10} \mathrm{z}$ podpisem urzędowo poświadczonym ${ }^{11}$. Faktu tego nie można wykazywać innymi dowodami ${ }^{12}$. W praktyce sądowej dokumentami urzędowymi, które umożliwiają uzyskanie klauzuli wykonalności na rzecz (lub przeciwko) następcy prawnemu, są m.in. orzeczenia sądowe, akty notarialne czy też odpisy z Krajowego Rejestru Sądowego. Natomiast za najczęściej powoływany dokument prywatny z podpisem urzędowo poświadczonym uznać należy umowę cesji z podpisem poświadczonym notarialnie.

Uchwała podjęta przez Sąd Najwyższy w dniu 8 listopada 2019 r. niewątpliwie pozostaje $\mathrm{w}$ związku $\mathrm{z}$ drugą ze wskazanych funkcji art. 788 $\S 1$ K.p.c., tj. funkcją dowodową, i dotyczy istotnego, z punktu widzenia praktyki sądowej, zagadnienia. Glosowane orzeczenie wyczerpuje wątpliwości orzecznicze, jakie mogą wystąpić przy ocenie dokumentu prywatnego z podpisem notarialnie poświadczonym (a zatem jednego z rodzajów urzędowego poświadczenia podpisu) w kontekście dowodu przejścia uprawnień (obowiązków) na następcę prawnego pierwotnego wierzyciela (dłużnika) ${ }^{13}$.

9 Jak wskazuje M. Rejdak (Kodeks postępowania cywilnego, t. 2: Komentarz do art. 205(1)424(12), red. A. Marciniak, Warszawa 2019, s. 270), aby dokument uzyskał status dokumentu urzędowego, musi spełniać kumulatywnie trzy przesłanki: 1) pochodzić od podmiotów prawa publicznego, czyli od organów władzy publicznej i innych organów państwowych w zakresie ich działania, a także innych podmiotów, w zakresie zleconych im przez ustawę zadań z dziedziny administracji publicznej (kryterium podmiotu); 2) zostać wydany w przepisanej formie (kryterium formy); 3) zostać wydany w zakresie działania organu, od którego pochodzi (kryterium przedmiotowe).

10 Dokumentem prywatnym jest natomiast każdy dokument pisemny lub elektroniczny, który nie odpowiada wymaganiom przewidzianym dla dokumentu urzędowego.

11 Zauważyć należy, że pojęciem ustawowym jest dokument prywatny z podpisem urzędowo poświadczonym. Dokument prywatny będzie spełniał wymogi dokumentu prywatnego z podpisem poświadczonym urzędowo nie tylko wówczas, gdy własnoręczność podpisu zostanie potwierdzona przez notariusza, lecz także - stosownie do treści rozporządzenia Ministra Sprawiedliwości z dnia 7 lutego 2007 r. w sprawie sporządzania niektórych poświadczeń przez organy samorządu terytorialnego i banki, Dz. U. z 2007 r. Nr 27, poz. 185 - przez wójta (burmistrza, prezydenta miasta) oraz banki.

12 K. Markiewicz, Czy w świetle art. 788 § 1 k.p.c. podstawa nadania klauzuli wykonalności może być poświadczony odpis dokumentu?, Polski Proces Cywilny 2010, nr 1, s. 85.

13 Zagadnienie dokumentów prywatnych z podpisem notarialnie poświadczonym w świetle funkcji dowodowej art. 788 § 1 K.p.c. stanowiło m.in. przedmiot uchwały Sądu Najwyższego z dnia 19 listopada 2010 r., III CZP 82/10, OSNC 2011, nr 6, poz. 62 oraz z dnia 13 maja 2015 r., III CZP 15/15. W pierwszym ze wskazanych orzeczeń Sąd 
W analizowanej sprawie Sąd Najwyższy słusznie przyjął, że dokument $\mathrm{z}$ podpisem uznanym przed notariuszem za własnoręczny jest dokumentem prywatnym z podpisem urzędowo poświadczonym w rozumieniu art. 788 § 1 K.p.c. Konstatację tę Sąd Najwyższy wyprowadził z okoliczności, że przepisy Prawa o notariacie ustanawiają dwie formy poświadczenia podpisu, przy czym żadnej z tychże form nie nadają mocy silniejszej w stosunku do drugiej. Stanowisko to - wprawdzie trafne - jednakże wymaga szerszej analizy niż ta, którą zaprezentował Sąd Najwyższy w uzasadnieniu komentowanej uchwały.

Zakres czynności dokonywanych przez notariusza określa treść art. 79 Prawa o notariacie. Stosownie do art. 79 pkt 2) w zw. z art. 96 pkt 1 tejże ustawy notariusz sporządza poświadczenia własnoręczności podpisu. Natomiast w świetle art. 88 Prawa o notariacie ${ }^{14}$ podpisy na aktach no-

Najwyższy stwierdził, że przy dokonywaniu czynności poświadczenia własnoręczności podpisu na dokumencie notariusz nie ma obowiązku badania zgodności z prawem treści tego dokumentu. Natomiast w drugiej uchwale Sąd Najwyższy uznał, że dokument zawierający oświadczenie notariusza o istnieniu podpisów notarialnie poświadczonych na oryginale umowy, na podstawie której uprawnienie wierzyciela lub obowiązek dłużnika przeszły po powstaniu tytułu egzekucyjnego na inną osobę, złożone na poświadczeniu zgodności wyciągu z tej umowy z jej oryginałem, jest dokumentem prywatnym z podpisem urzędowo poświadczonym w rozumieniu art. 788 § 1 K.p.c. Za istotną uznać także należy uchwałę z dnia 21 grudnia 2010 r., III CZP 94/10, OSNC 2011, nr 9, poz. 91 z glosą T. Szanciło, Uprawnienie petnomocników do poświadczania dokumentów, Monitor Prawniczy 2012, nr 8, s. 439-441 oraz uchwałę z 21 grudnia 2010 r., III CZP 98/10, OSNC 2011, nr 9, poz. 92, w których Sąd Najwyższy jako podstawę nadania klauzuli wykonalności na rzecz następcy prawnego wierzyciela na podstawie art. 788 \& 1 K.p.c. dopuścił kopię odpisu z Krajowego Rejestru Sądowego, poświadczoną za zgodność z oryginałem przez pełnomocnika wnioskodawcy, będącego radcą prawnym. Wprawdzie orzeczenie to zostało wydane w odwołaniu do dokumentu urzędowego poświadczonego za zgodność z oryginałem, jednakże wywiedziona reguła znajduje zastosowanie także wobec dokumentów prywatnych z podpisem urzędowo poświadczonym.

14 Konstrukcja poświadczenia własnoręczności podpisu, uregulowana w art. 88 Prawa o notariacie, nie stanowi novum w stosunku do wcześniej obowiązującego ustawodawstwa dotyczącego czynności notarialnych. Dwojaką możliwość stwierdzenia własnoręczności podpisu na przedstawionym notariuszowi dokumencie prywatnym przewidywały bowiem zarówno przepisy art. 96 § 2 Rozporządzenia Prezydenta Rzeczypospolitej z dnia 27 października 1933 r. - Prawo o notarjacie, Dz. U. z 1933 r. Nr 84, poz. 609 z późn. zm., jak i art. 52 § 2 ustawy z dnia 25 maja 1951 r. - Prawo o notariacie, tekst jednolity: Dz. U. z 1963 r. Nr 19, poz. 106 z późn. zm., zgodnie z których treścią notariusz poświadczał, że podpis został położony w jego obecności bądź uznany za własny. Natomiast przepis art. 66 § 1 pkt 1) ustawy z dnia 24 maja 1989 r. - Prawo o notariacie, Dz. U. z 1989 r. Nr 33, 
tarialnych i poświadczonych dokumentach składane są w obecności notariusza. Jeżeli podpis na poświadczonym dokumencie był złożony nie w obecności notariusza, osoba, która podpisała, powinna uznać przed notariuszem złożony podpis za własnoręczny ${ }^{15}$. Okoliczność tę notariusz zaznacza w sporządzonym dokumencie.

Literalne brzmienie przywołanej powyżej regulacji prowadzi do wniosku, że notariusz, w zależności od tego, czy podpis jest składany w jego obecności, czy też nie, swoim poświadczeniem de facto obejmuje dwie różne okoliczności ${ }^{16}$. W pierwszym przypadku, gdy podpis na dokumencie składany jest w obecności notariusza. Tym samym sporządzona klauzula poświadczeniowa potwierdza wprost własnoręczność podpisu. Notariusz jest naocznym świadkiem czynności polegającej na złożeniu podpisu na dokumencie prywatnym przez daną osobę. Natomiast w przypadku objętym dyspozycją art. 88 zd. drugie Prawa o notariacie klauzula poświadczeniowa ogranicza się $\mathrm{w}$ istocie do stwierdzenia, że dana osoba uznała $\mathrm{w}$ obecności notariusza dokument za własnoręcznie podpisany ${ }^{17}$. Czynność dokonywana przed notariuszem jest zatem działaniem o charakterze następczym w odniesieniu do samego sporządzenia podpisu. Notariuszowi przedstawiany jest bowiem dokument, który wcześniej został podpisany przez stawającego. W takiej sytuacji notariusz zasadniczo nie może żądać, aby stawający ponownie złożył podpis i dopiero wówczas sporządzić

poz. 176 z późn. zm., stanowił jedynie, że notariusz poświadcza własnoręczność podpisu. Warto przy tym odnotować, że w świetle przywołanych regulacji z 1933 r. i 1951 r. notariusz był jednak zobligowany do zapoznania się z treścią okazywanego mu dokumentu, poświadczenia podpisu zaś dokonywał, w sytuacji gdy treść takiego dokumentu nie była sprzeczna z przesłankami wskazanymi w ustawie. Obecnie obowiązujące Prawo o notariacie nie stawia przed notariuszami wymogu zapoznania się z treścią poświadczanego dokumentu ani też dokonania jego oceny pod względem np. sprzeczności z prawem.

15 Na temat pojęcia „własnoręczności” podpisu zob. G. Wolak, Z problematyki „własnoręczności" podpisu (art. 78 § 1 KC), Monitor Prawniczy 2012, nr 18, s. 967-973 i przywołana tam literatura.

16 K. Górska, Ocena dochowania formy szczególnej czynności prawnej w aspekcie czasowym - uwagi na tle wyroku SN z 29 stycznia 2009 r., V CSK 294/08, w: Wybrane zagadnienia polskiego prawa prywatnego: księga pamiątkowa ku czci Doktora Józefa Kremisa i Doktora Jerzego Strzebinczyka, red. J. Jezioro, K. Zagrobelny, Wrocław 2019, s. 90.

17 A.J. Szereda, Czynności notarialne. Komentarz do art. 79-112 Prawa o notariacie, Warszawa 2018, [System Informacji Prawnej Legalis, dostęp: 5.01.2020 r.], Komentarz do art. 88, teza 4.A. 
klauzulę poświadczeniową ${ }^{18}$. Rola notariusza sprowadza się do odebrania oświadczenia, że to właśnie stawający jest autorem widniejącego już na dokumencie podpisu. Co istotne, nie chodzi tutaj o ewentualne konwalidowanie dokonanej czynności, oceniając przez pryzmat przepisów materialnoprawnych.

Pomimo różnic występujących $\mathrm{w}$ formułach obu poświadczeń ich rola jest tożsama. Bez względu bowiem na treść sporządzanego poświadczenia każde $\mathrm{z}$ nich jest wzmianką umieszczoną przez notariusza na dokumencie, że złożony podpis pochodzi od osoby, na którą wskazuje jego treść ${ }^{19}$. Stanowi więc identyfikację określonej osoby jako autora oświadczenia zawartego $\mathrm{w}$ dokumencie. W konsekwencji także wartość dowodowa sporządzanych poświadczeń jest tożsama. Nie bez znaczenia pozostaje przy tym okoliczność, że zarówno dokonując poświadczenia własnoręczności podpisu, jak i poświadczenia uznania podpisu za własnoręczny, notariusz zobligowany jest ustalić tożsamość osoby, której podpis ma zostać poświadczony ${ }^{20}$. Brak jest natomiast argumentów, które pozwalałyby stwierdzić, że złożenie podpisu w obecności notariusza zapewnia większy poziom obiektywizmu i niezależności notariusza niż w przypadku odebrania oświadczenia o własnoręczności podpisu w świetle art. 788 § 1 K.p.c.

Ponadto pamiętać należy, że potwierdzenie przez notariusza własnoręczności podpisu, bez względu na jego formę, nie nadaje dokumentom prywatnym mocy dokumentów urzędowych. $Z$ formalnoprawnego punktu widzenia moc dokumentów urzędowych - podobnie zresztą jak

18 Prawo o notarjacie, oprac. M. Allerhand, Lwów 1934, s. 142. Autor zauważył jednocześnie, że w sytuacji, gdyby stawający oświadczył, że podpis nie pochodzi od niego, jednakże uznawałby widniejący podpis za własny, notariusz ma obowiązek żądać złożenia podpisu w jego obecności.

19 M. Grochowski, w: Prawo o notariacie. Komentarz, red. K. Osajda, 2019, [System Informacji Prawnej Legalis, dostęp: 5.01.2020 r.], Komentarz do art. 88, teza 1.

20 Przepisy art. 85 Prawa notariacie nakładają na notariuszy obowiązek stwierdzenia tożsamości osób biorących udział przy dokonywaniu czynności notarialnej na podstawie prawem przewidzianych dokumentów, a w przypadku braku takich dokumentów w sposób wyłączający wszelką wątpliwość co do określenia tożsamości osoby biorącej udział w czynności notarialnej. W praktyce stwierdzenie tożsamości osób biorących udział w czynności notarialnej może nastąpić na podstawie takich dokumentów jak dowód osobisty czy też paszport. Dopuszczenie do udziału w czynności notarialnej osoby o nieustalonej tożsamości powinno prowadzić do pozbawienia dokumentu notarialnego charakteru dokumentu urzędowego. 
w wypadku poświadczenia zgodności odpisu, wyciągu lub kopii z okazanym dokumentem - mają jedynie klauzule poświadczeniowe ${ }^{21}$. Okoliczność ta wynika z dyspozycji art. 2 § 2 Prawa o notariacie, zgodnie z którym czynności notarialne, dokonane przez notariusza zgodnie z prawem, mają charakter dokumentu urzędowego. W świetle powyższych uwag Sąd Najwyższy trafnie stwierdził, że w obecnym stanie prawnym brak jest przesłanek do uznania, że podpis uznany przed notariuszem za własny ma mniejszą moc niż podpis, który został złożony fizycznie w obecności notariusza lub wręcz tej mocy jest pozbawiony.

Zauważyć także należy, że konstatacja wyrażona w komentowanym orzeczeniu stanowi kontynuację stanowiska Sądu Najwyższego zaprezentowanego w uchwale z dnia 13 maja 2015 r., w sprawie III CZP 15/15. Sąd Najwyższy stwierdził wówczas, że urzędowe poświadczenie podpisu na dokumencie prywatnym (art. $788 \S 1$ K.p.c.) może być dokonane także w innym czasie niż czynność prawna, na podstawie której uprawnienie wierzyciela lub obowiązek dłużnika przeszły po powstaniu tytułu egzekucyjnego na inną osobę. Bez wątpienia, w przypadku dokumentu z podpisem uznanym przed notariuszem za własnoręczny nie tylko dochodzi do urzędowego poświadczenia podpisu na dokumencie prywatnym, lecz także poświadczenie to następuje w innym czasie niż czynność prawna, skutkująca przejściem uprawnień lub obowiązków.

Zasadnie również Sąd Najwyższy nie podzielił obaw Sądu Rejonowego odnośnie do tego, że możliwość uznania przed notariuszem podpisu na dokumencie prywatnym za własnoręczny stwarza poważne niebezpieczeństwo dla obrotu prawnego ${ }^{22}$, przy czym argumentacja przywołana przez Sąd Najwyższy na poparcie swojego stanowiska (aczkolwiek słusznego) może wywoływać pewne wątpliwości. Przede wszystkim dziwić może okoliczność, że Sąd Najwyższy nie odwołał się do statusu prawnego notariuszy i ich roli w polskim systemie prawnym. Nie można bowiem tracić z pola widzenia, że notariusz jest zawodem zaufania publicznego, a jego zadaniem jest właśnie zapewnienie bezpieczeństwa

21 K. Górska, Ocena dochowania..., s. 91.

22 Stanowisko Sądu Rejonowego zaprezentowane w uzasadnieniu rozstrzyganego zagadnienia prawnego jest tożsame $\mathrm{z}$ poglądem wyrażonym $\mathrm{w}$ literaturze przedmiotu przez A. Tkaczyńskiego, Notarialne poświadczenie podpisu - wybrane problemy, w: Księga dla naszych kolegów. Prace prawnicze poświęcone pamięci doktora Andrzeja Ciska, doktora Zygmunta Masternaka i doktora Marka Zagrosika, red. J. Mazurkiewicz, Wrocław 2013, s. 453-459. 
obrotu prawnego i wiarygodności ${ }^{23}$. Dokonując jakiejkolwiek czynności notarialnej, a zatem także poświadczenia podpisu w sposób, o którym mowa w art. $88 \mathrm{zd}$. drugie Prawa o notariacie, jest on związany obowiązkami przewidzianymi w przepisach Prawa o notariacie, w szczególności w art. 81 Prawa o notariacie oraz art. 86 Prawa o notariacie. Notariusz jest zobligowany zatem odmówić poświadczenia uznania podpisu za własnoręczny, w sytuacji gdy uzna, że czynność ta jest sprzeczna z prawem. Nie wolno mu również dokonać tej czynności, jeżeli poweźmie wątpliwość, czy strona czynności notarialnej ma zdolność do czynności prawnych ${ }^{24}$.

Wbrew poglądowi Sądu Najwyższego w przypadku jakichkolwiek wątpliwości dotyczących wartości dowodowej dokumentu prywatnego, o którym mowa w art. 788 K.p.c., trudno mówić o celowości zastosowania przepisu art. 760 § 2 K.p.c., zgodnie z którym, w przypadku gdy według przepisów niniejszego Kodeksu zachodzi potrzeba wysłuchania strony, wysłuchanie odbywa się, stosownie do okoliczności, przez spisanie protokołu w obecności lub nieobecności drugiej strony albo przez oświadczenie strony złożone na piśmie lub za pośrednictwem systemu teleinformatycznego ${ }^{25}$. Wprawdzie w literaturze przedmiotu wskazuje się na możliwość zastosowania przywołanej powyżej regulacji także $\mathrm{w}$ postępowaniu klauzulowym ${ }^{26}$, nie sposób jednak wyobrazić sobie, w jaki ewentualnie

23 Uchwała Sądu Najwyższego z dnia 18 grudnia 2013 r., III CZP 82/13, OSNC 2014, nr 10, poz. 101.

${ }^{24} \mathrm{Na}$ temat odmowy dokonania czynności notarialnej szerzej np.: A. Oleszko, Odmowa sporządzenia czynności notarialnej, Rejent 1996, nr 4-5(60-61), s. 45-59; J. Matys, Zasady wspótżycia społecznego jako podstawa odmowy dokonania czynności notarialnej (uwagi na tle art. 81 Prawa o notariacie), Białostockie Studia Prawnicze 2014, nr 17, s. 155-168; J. Budzianowska, Odmowa dokonania czynności notarialnej, Nowy Przegląd Notarialny 2000, nr 1, s. 44-73; M. Nowocień, Nieświadomość jako przyczyna odmowy dokonania czynności notarialnej, Monitor Prawniczy 2013, nr 24, s. 1300-1306; E. Gniewek, O potrzebie szczególnej ostrożności notariusza przy dokonywaniu czynności z udziałem osób starszych, Rejent 2000, nr 5(109), s. 210-217; M. Łata, Bezstronność (sensu stricto) notariusza, Rejent 2018, nr 7(327), s. 21-40.

25 Przepis art. 760 K.p.c. nie statuuje obowiązku wysłuchania, lecz określa jedynie sposób jego przeprowadzenia.

${ }^{26}$ W literaturze przedmiotu na możliwość tego rodzaju rozwiązania wskazuje m.in. Z. Szczurek, Egzekucja sądowa w sprawach cywilnych, Sopot 2011, [baza danych LEX, dostęp: 11.01.2020 r.]; M. Muliński, w: Kodeks postępowania cywilnego. Koszty sądowe w sprawach cywilnych. Dochodzenie roszczeń w postępowaniu grupowym. Przepisy przejściowe. Komentarz do zmian, t. 1-2, red. T. Zembrzuski, Warszawa 2020 [baza danych LEX, dostęp: 11.01.2020 r.], Komentarz do art. 760, teza 14. Warto w tym miejscu odnotować, że do dnia wejścia w życie ustawy z dnia 17 czerwca 2004 r. o zmianie ustawy - Kodeks rodzinny 
sposób wysłuchanie uczestników tego postępowania mogłoby rozwiać wątpliwości dotyczące wartości dowodowej dokumentu prywatnego $\mathrm{z}$ podpisem notarialnie poświadczonym w trybie art. $88 \mathrm{zd}$. drugie Prawa o notariacie. Oczywista bowiem wydaje się konstatacja, że ewentualne wysłuchanie niebędące środkiem dowodowym ${ }^{27}$ nie może doprowadzić do obalenia domniemań wynikających z uznania sporządzonej przez notariusza klauzuli poświadczeniowej za dokument urzędowy, o którym mowa w art. 244 K.p.c., tj. domniemania prawdziwości (autentyczności) oraz domniemania zgodności z prawdą tego, co zostało w nim urzędowo zaświadczone. Podzielić należy pogląd, że w sprawie o nadanie klauzuli wykonalności w trybie art. 788 K.p.c. wysłuchanie strony może mieć jedynie charakter pomocniczy, a nie decydujący, nawet wtedy, gdy zaistniała szczególna sytuacja ${ }^{28}$.

W świetle powyższych rozważań, niezależnie od zgłoszonych uwag, glosowana uchwała Sądu Najwyższego zasługuje na aprobatę.

Pomimo trafności stanowiska Sądu Najwyższego wydaje się, że komentowane orzeczenie nie spowoduje jednak znaczącego wzrostu uwzględniania wniosków o nadanie klauzuli wykonalności w trybie art. 788 § 1 K.p.c. w oparciu o dokumenty prywatne z podpisem urzędowo poświadczonym, w szczególności umowę cesji z podpisem notarialnie poświadczonym. Z orzecznictwa sądów powszechnych wynika bowiem, że przeszkodą do uzyskania klauzuli wykonalności na rzecz następcy prawnego na podstawie tego rodzaju dokumentu prywatnego z podpisem urzędowo poświadczonym jest nie tyle problem zachowania jego formy w odniesieniu do samej umowy cesji, ile jej załączników zawierających wykaz wierzytelności objętych treścią umowy lub ogólnikowego sformułowania klauzuli poświadczeniowej ${ }^{29}$.

i opiekuńczy oraz niektórych innych ustaw, Dz. U. z 2004 r. Nr 162, poz. 1691, obowiązek wysłuchania w postępowaniu klauzulowym przewidywał ówczesny przepis art. 787 § 1 in fine K.p.c. w odniesieniu do małżonka dłużnika.

27 Z. Szczurek, Gromadzenie informacji i ustalanie okoliczności faktycznych i prawnych niezbędnych dla prowadzenia egzekucji sądowej, Gdańskie Studia Prawnicze 2016, t. 36, nr 2, s. 436.

28 P. Rawczyński, Nadanie tytułowi egzekucyjnemu klauzuli wykonalności przy zmianach podmiotowych w trybie art. 788 § 1 k.p.c., Przegląd Prawa Egzekucyjnego 2010, nr 7 , s 28.

29 Stwierdzić należy, że sądy rozpoznające zażalenia lub skargi na postanowienia oddalające wnioski o nadanie klauzuli wykonalności w trybie art. 788 § 1 K.p.c. konsekwentnie przyjmują, że wymóg przedstawienia dokumentu prywatnego z podpisem urzędowo poświadczonym dotyczy wszystkich elementów czynności, w następstwie której nastąpiła 


\section{Bibliografia}

Górska K., Ocena dochowania formy szczególnej czynności prawnej w aspekcie czasowym - uwagi na tle wyroku SN z 29 stycznia 2009 r., V CSK 294/08, w: Wybrane zagadnienia polskiego prawa prywatnego: księga pamiątkowa ku czci Doktora Józefa Kremisa i Doktora Jerzego Strzebinczyka, red. J. Jezioro, K. Zagrobelny, Wrocław 2019.

Kowalski K., Glosa do uchwaty Sądu Najwyższego z 13.05.2015 r., III CZP 15/15, Rejent 2017, nr 11(319).

Marciniak A. (red.), Kodeks postepowania cywilnego, t. 2: Komentarz do art. 205(1)-424(12), Warszawa 2019.

Osajda K. (red.), Prawo o notariacie. Komentarz, wyd. 3, Legalis.

Prawo o notarjacie, oprac. M. Allerhand, Lwów 1934.

Puć D., Postępowanie w przedmiocie nadania klauzuli wykonalności na rzecz następcy prawnego, w: Aktualne problemy prawa materialnego i procesowego cywilnego, red. E. Marszałkowska-Krześ, Wrocław 2019.

Stanik M., Dowody z dokumentów poświadczonych za zgodność z oryginałem przez profesjonalnego petnomocnika w postepowaniu w sprawie o wpis w Krajowym Rejestrze Sądowym, Zeszyty Prawnicze 2013, t. 13, z. 3.

Szereda A.J., Czynności notarialne. Komentarz do art. 79-112 Prawa o notariacie, wyd. 1, Warszawa 2018.

Tkaczyński A., Notarialne poświadczenie podpisu - wybrane problemy, w: Księga dla naszych kolegów. Prace prawnicze poświęcone pamięci doktora Andrzeja Ciska, doktora Zygmunta Masternaka i doktora Marka Zagrosika, red. J. Mazurkiewicz, Wrocław 2013.

Zieliński A., Flaga-Gieruszyńska K., Kodeks postępowania cywilnego. Komentarz, wyd. 10, Warszawa 2019.

zmiana wierzyciela. W konsekwencji, gdy treść załącznika jest wyłączona poza podpisaną treść umowy cesji, wnioskodawca powinien wykazać, że załącznik również został sporządzony z urzędowo poświadczonymi podpisami osób zawierających umowę. Ponadto, niejednokrotnie z treści klauzuli poświadczeniowej nie wynika, do jakiego dokumentu się odnosi. Notariusze posługują się bowiem klauzulami zawierającymi ogólnikowymi sformułowaniami jak „powyższe podpisy na niniejszym dokumencie”. Zob. np.: postanowienie Sądu Okręgowego w Gliwicach z dnia 6 lutego 2017 r., III Cz 2037/18, http://orzeczenia. gliwice.so.gov.pl/content/\$N/151515000001503_III_Cz_002037_2017_Uz_2018-02-06_001 [dostęp: 4.01.2020 r.], postanowienie Sądu Okręgowego w Kaliszu z dnia 28 marca 2017 r., II Cz 102/17, http://orzeczenia.kalisz.so.gov.pl/content/\$N/152505000001003_II_ Cz_000102_2017_Uz_2017-03-28_001 [dostęp: 4.01.2020 r.], postanowienie Sądu Okręgowego w Świdnicy z dnia 26 września 2017 r., II Cz 742/17, http:/ / orzeczenia.swidnica.so.gov.pl/ content/\$N/155020000001003_II_Cz_000742_2017_Uz_2017-09-26_001 [dostęp: 4.01.2020 r.]. 


\section{Streszczenie}

W świetle dyspozycji art. 788 § 1 K.p.c. dowody przedstawione przez wnioskodawcę odgrywają kluczową rolę dla uzyskania klauzuli wykonalności na rzecz (przeciwko) następcy prawnego pierwotnego wierzyciela (dłużnika). Skuteczne wykazanie przejścia uprawnień lub obowiązków na rzecz następcy prawnego w tym przypadku możliwe jest wyłącznie na podstawie dokumentów urzędowych lub dokumentów prywatnych z podpisem urzędowo poświadczonym. Glosowane orzeczenie wyczerpuje wątpliwości orzecznicze, jakie mogą powstać przy ocenie dokumentu prywatnego z podpisem notarialnie poświadczonym (a zatem jednego z rodzajów urzędowego poświadczenia podpisu) w kontekście dowodu przejścia uprawnień (obowiązków) na następcę prawnego pierwotnego wierzyciela (dłużnika).

Słowa kluczowe: następstwo prawne, notarialne poświadczenie podpisu, postępowanie klauzulowe, dokument prywatny z podpisem urzędowo poświadczonym, bezpieczeństwo obrotu prawnego

\section{GLOSS TO THE JUDGMENT OF THE SUPREME COURT OF NOVEMBER 8, 2019, THE FILE REFERENCE NUMER III CZP 26/19}

\section{Sum mary}

In accordance with art. $788 \S 1$ of the Code of Civil Procedure, evidence provided by the applicant plays a key role in obtaining an enforcement clause in favor of (against) the legal successor of the original creditor (debtor). The effective demonstration of the transfer of rights or obligations to the legal successor in this case is possible only on the basis of official documents or private documents with an officially certified signature. The judgment exhausts the judicial doubts that may arise when assessing a private document with a notarially authenticated signature (and thus one of the types of official signature confirmation) in the context of proof of transfer of rights (obligations) to the legal successor of the original creditor (debtor).

Key words: legal succession, notarial signature confirmation, clausule procedure, private document with an officially certified signature, security of conduct of legal transactions 


\section{КОММЕНТАРИЙ К ПОСТАНОВЛЕНИЮ ВЕРХОВНОГО СУДА ОТ 8 НОЯБРЯ 2019 Г., ІІІ ЧП 26/19 \\ Резюме}

В соответствии со ст. 788 § 1 Гражданского процессуального кодекса доказательства, представленные заявителем, играют ключевую роль в получении исполнительной надписи в отношении (против) правопреемника первоначального кредитора (должника). В этом случае эффективное доказательство перехода прав или обязанностей к правопреемнику возможно только на основании официальных документов или частных документов с официально заверенной подписью. Комментируемое судебное решение исчерпывает сомнения судебной практики, которые могут возникнуть при оценке частного документа с нотариально заверенной подписью (то есть одного из видов официального удостоверения подлинности подписи) в контексте доказательства перехода прав (обязанностей) к правопреемнику первоначального кредитора (должника).

Ключевые слова: правопреемство, нотариальное заверение подписи, исполнительное производство, частный документ с официально заверенной подписью, безопасность правового оборота 
